\title{
Novel Therapeutics for Multiple Sclerosis Designed by Parasitic Worms
}

\author{
Aakanksha Dixit ${ }^{1}$, Akane Tanaka ${ }^{2}$, Judith M. Greer ${ }^{1}$ and Sheila Donnelly ${ }^{2, *}$ \\ 1 The University of Queensland, UQ Centre for Clinical Research, Brisbane, QLD 4029, Australia; \\ a.dixit@uq.edu.au (A.D.); j.greer@uq.edu.au (J.M.G.) \\ 2 The School of Life Sciences, University of Technology Sydney, Ultimo, NSW 2007, Australia; \\ akane.tanaka@uts.edu.au \\ * Correspondence: sheila.donnelly@uts.edu.au; Tel.: +61-2-9514-4318
}

Received: 9 September 2017; Accepted: 11 October 2017; Published: 13 October 2017

\begin{abstract}
The evolutionary response to endemic infections with parasitic worms (helminth) was the development of a distinct regulatory immune profile arising from the need to encapsulate the helminths while simultaneously repairing tissue damage. According to the old friend's hypothesis, the diminished exposure to these parasites in the developed world has resulted in a dysregulated immune response that contributes to the increased incidence of immune mediated diseases such as Multiple Sclerosis (MS). Indeed, the global distribution of MS shows an inverse correlation to the prevalence of helminth infection. On this basis, the possibility of treating MS with helminth infection has been explored in animal models and phase 1 and 2 human clinical trials. However, the possibility also exists that the individual immune modulatory molecules secreted by helminth parasites may offer a more defined therapeutic strategy.
\end{abstract}

Keywords: multiple sclerosis; environmental factors; helminth parasites; old friend's hypothesis; immune modulation; innate immunity

\section{Introduction}

Multiple Sclerosis (MS) is an autoimmune demyelinating disease that can manifest as a wide range of clinical signs and symptoms and present with varying severity. It is generally accepted that a combination of individual genetic susceptibility and environmental factors contribute to the development of autoimmune diseases like MS, although the relative contribution of each of these factors is hotly debated [1,2].

Genome wide association studies (GWAS) of MS patients have identified over 100 genetic risk loci. However, most of these exert only a modest influence on MS risk and contribute only $20-30 \%$ of the perceived heritability of MS, suggesting that the remaining $70-80 \%$ of unexplained susceptibility is affected by environmental factors [2-4]. Furthermore, in studies of identical twins where one develops MS, only $25 \%$ of second twins developed the disease [5]. Such discordance between monozygotic twins strongly supports a critical role for an environmental factor in the initiation of MS. However, perhaps the most compelling evidence in this regard has been the rapid increase in the incidence rates of MS in the developed world over recent years [6-9]. This rise far exceeds the rate of population evolution and therefore implies either the removal of protective factors or the introduction of susceptibility factors in the environment. Indeed, population migration studies indicate that the place of residence in adolescence or early adulthood strongly influences a person's subsequent risk of MS [10-13].

Identification of the possible environmental factors has been informed by the unusual geographic distribution of the disease. The prevalence of MS increases with increasing latitude, such that higher rates of incidence are found in high latitude regions $[4,14]$. MS is also more common in the developed 
world than the developing world [15]. Based on these epidemiological observations, several putative environmental risk factors have been proposed such as low vitamin D, Epstein-Barr virus, sanitation and smoking [4,15-17]. However, perhaps the most compelling environmental relationship is the worldwide inverse correlation between infections with parasitic worms (helminths) and the incidence of autoimmune disease [18].

Corroborating this hypothesis, longitudinal and migratory studies evaluating the prevalence of MS in the French West Indies over a period of 20 years showed that increased MS incidence in the region was associated with a significant reduction of parasite infections during the same time period [19]. More specifically, the prevalence of MS was reportedly significantly reduced once a critical threshold $(10 \%)$ of infection with the helminth Trichuris trichiura was exceeded in any given population [20]. The fact that administration of anti-helminth drugs resulted in increased MS activity [21], suggests that helminths directly suppress autoimmune diseases and may be the protective environmental factor against the development of MS.

\section{Should We Reunite with Our Old Friends the Helminth Parasites?}

The human immune system evolved to provide protection from a range of pathogenic microorganisms (viruses, bacteria, fungi and protozoan). However, despite also being regarded as pathogenic, the immune response to helminth parasites does not typically provide protection from re-infection. Instead, most of these organisms are well tolerated by their human hosts, with infections lasting for many years [22]. Moreover, infections are primarily asymptomatic and mortality is rare. It is suggested that this phenomenon has occurred due to the long evolutionary coadaptation between these parasites and man [23,24], through which helminth parasites have strongly influenced the evolution of the human immune system. This is because infection was not associated with the onset of epidemics but rather helminth parasites have been ubiquitous within human populations over millennia [23].

The canonical immune response to helminth parasite infection is the development of an anti-inflammatory, type 2 immune response, characterised by the secretion of cytokines Interleukin (IL)-4, IL-5, IL-9 and IL-13 [25-27], and the simultaneous suppression of pro-inflammatory Thelper (Th)- 1 and Th17 responses [28]. Initially, it was thought that these type 2 cytokines were produced by Th2 cells. However, several studies have demonstrated that the helminth-induced type 2 responses can be generated in the absence of $\mathrm{T}$ cells [29] and have led to the recent identification of a non-redundant role for type 2 innate lymphoid cells (ILC2) in the recognition and response to parasitic worms [30]. ILC2 secrete IL-4, IL-5, IL-13 and amphiregulin to combat helminth infection [31]. This switch towards a type 2 immune response also leads to the inhibition of pro-inflammatory M1 macrophages and dendritic cells (DCs) and, instead, the induction of an immature phenotype of dendritic cells (DC2s) and an anti-inflammatory phenotype of macrophage (termed helminth-M2 macrophages) [32]. As the parasite infection reaches chronicity, the differentiation of T-regulatory (Treg) populations is initiated. These cells secrete regulatory cytokines, such as IL-10 and transforming growth factor- $\beta$ (TGF- $\beta$ ) [33], which further inhibit Th1 responses, and also regulate type 2 responses. This prevents the generation of extensive tissue fibrosis, which would result from sustained wound healing activity mediated by helminth-M2 macrophages and their products [34].

The outcome for the host is to create a balance in which the parasite is tolerated, and homeostasis can be maintained. It is suggested that the Treg response is crucial for invoking specific immunological tolerance. However, when damage does occur, a more physiological tolerance mechanism, including the ability to repair the damage, is maintained by type 2 effector pathways [35].

This evolutionary development in immune responsiveness to infection with helminths has resulted in compensatory adjustments to immune-related genes in human populations [36,37]. In fact, it has been proposed that, in order for the human immune system to operate optimally, the presence of helminth induced immunoregulatory networks are required [38]. Accordingly, in populations where parasitic infections are no longer endemic, there is an increased likelihood of inappropriate immune responsiveness to autoantigens, and the concomitant development of autoimmune/inflammatory 
diseases, such as MS. Consequently, many have asked the question of whether helminths should be regarded as beneficial commensals and whether the re-introduction of these old friends may be therapeutic in MS [7,39-43].

\section{Worm Therapy: Proof-of-Principle in Experimental and Clinical Trials}

\subsection{Testing the Effectiveness of Helminth Infection in Animal Models of MS}

The most widely used animal model of MS is experimental autoimmune encephalomyelitis (EAE), which mimics several of the key clinical and pathological features of the human disease, such as paralysis and demyelination. EAE studies have provided critical information on autoimmune related central nervous system (CNS) damage, demyelination, presence of immunoglobulins in CNS and cerebrospinal fluid, distribution of lesions and remyelination processes, and much of our understanding of the likely pathological mechanisms in MS came from work using the EAE models.

EAE is actively induced in rodents via immunisation with a neuroantigen emulsified in adjuvant (typically complete Freund's adjuvant). The neuroantigen is typically a whole tissue homogenate (e.g., spinal cord), myelin protein (e.g., MOG, myelin oligodendrocyte glycoprotein), or purified myelin peptide (e.g., $\mathrm{MOG}_{35-55}, \mathrm{PLP}_{139-151}$ ). The experimental choice of animal, neuroantigen and adjuvant influences the outcome of EAE, which is quite variable (e.g., acute, relapsing, or chronic forms) [44]. After immunisation with the neuroantigen, there is typically an induction phase (0-10 days after immunisation) during which the autoreactive $\mathrm{T}$ cells are activated and disseminate. This is followed by the effector phase (10-30+ days after immunisation with neuroantigen) during which the autoreactive $\mathrm{T}$ cells in the CNS activate microglia and macrophages, which subsequently damage myelin and other CNS components. At this stage, signs of clinical disease, such as paresis and paralysis, are evident in the animals.

Encouragingly, of the 12 studies reported to date (Table 1), in all but one case, infection of rodents with helminth parasites protected the animals from EAE. The range of experimental design, dosing, treatment schedules and choice of helminth (and thus tissue site being colonised) make it challenging to determine a single specific mechanism of disease prevention. However, as expected for a helminth infection, in all cases, there was an overall switch in the autoantigen specific immune response from a pro-inflammatory Th1 and Th17 response towards a type 2 or Treg predominant response. In the majority of cases, the worms were administered to animals prior to the induction phase of disease (pre-induction), which, considering the parasite's ability to suppress pro-inflammatory immune responses, may simply reflect a suppression of the induction of immune responses to the administered neuroantigen. Alternatively, it could also be considered that such timing for therapeutic manipulation during EAE experiments best models the effect of preventive therapy for a new relapse or episode in MS [15]. More persuasive is the demonstration that, when delivered during the effector phase of the disease, the intestinal parasite $H$. polygyrus, mediated complete amelioration of the clinical signs of disease within six days [45]. In contrast, infection with the blood fluke S. mansoni was ineffective when delivered during the effector phase, despite showing efficacy when administered during the pre-induction or induction phases [46]. This suggests that not every helminth will offer beneficial effects and the choice of parasite may be the most critical factor in the development of worm therapeutics.

\subsection{Testing the Effectiveness of Helminth Infection in Human Trials}

The first direct evidence that helminth infection could prevent MS came from a series of observational studies beginning in 2007 [47]. This prospective investigation examined the clinical status of 12 relapsing-remitting MS subjects who had naturally contracted gastrointestinal parasites and compared them to a second cohort of demographically-matched MS patients without parasite infection. Over a period of 4.5 years, the patients infected with helminth parasites had a dramatic and sustained reduction in clinical, magnetic resonance imaging (MRI), and immunological parameters of 
MS activity, compared to the uninfected subjects. During the follow up study over the next $5-7$ years, one third of the patients infected with helminths developed severe gastrointestinal symptoms and were treated to clear the helminth [21]. Unfortunately, elimination of the parasites in those patients also resulted in a return of the clinical and MRI signs of disease to a level similar to that seen in the patients who were not infected. This finding provided support for the notion that helminth infection might be a useful therapeutic approach for the treatment of MS, and led to the initiation of several clinical trials using live helminth infection in patients with MS (summarized in Table 2).

To date, all phase 1 studies have shown that treatment with the helminths is safe. Some, but not all, have also shown promising effects on clinical outcomes, brain MRI measures. However, as efficacy was not the primary outcome of these studies, these data should be interpreted with caution. Over the last three years, two double-blinded, placebo-controlled phase 2 trials have been undertaken. One of these is still ongoing (HINT2) and although the second (WIRMS) is completed; the results have not yet been published. These studies will provide a comprehensive and meaningful outcome and determine the future of live worm therapeutics.

Analysis of systemic immunological changes in MS patients therapeutically infected with helminths reported a profile of beneficial immune modulation. A general increase in serum IL-4, IL-5 and IL-10 supported a helminth induced switch to Th2/Treg immune responses [48]. In addition, the secretion of IFN $\gamma$ from antigen stimulated $\mathrm{T}$ cells was significantly reduced, indicating a suppression of autoantigen specific Th1 responses [49]. A similar outcome has been reported in patients with inflammatory bowel disease and coeliac disease therapeutically infected with T. trichiura or hookworm, respectively [50,51]. In both cases, during parasite infection, the clinical symptoms of immune mediated disease abated in parallel with a decrease in IL-17 producing T cells. However, in these particular disease indications, the immune modulation promoted by parasite infection also mediated physiological changes to improve clinical symptoms. The accumulation of IL-22 producing T cells in the intestinal mucosa of infected patients was suggested to promote intestinal mucus production to reduce symptomatic colitis [50]. While similar relationships have not yet been investigated for helminth infected MS patients, given the growing evidence for functional crosstalk between the gut and the CNS, it is possible that intestinal immunological changes occurring in response to helminth infection is causally related to a positive modulation of brain autoimmunity. 
Table 1. Studies reporting live helminth infection in animal models of Experimental Autoimmune Encephalomyelitis.

\begin{tabular}{|c|c|c|c|c|c|c|}
\hline \multirow{2}{*}{ Animal Model a } & \multirow{2}{*}{ Helminth Treatment ${ }^{b}$} & \multicolumn{3}{|c|}{ Effects When Treatment Administered at ${ }^{\mathrm{c}}$} & \multirow{2}{*}{ Mechanism } & \multirow{2}{*}{ Ref. } \\
\hline & & Pre-Induction & Induction & Effector & & \\
\hline \multirow{2}{*}{$\mathrm{PLP}_{139-151}$ SJL mice } & Schistosoma mansoni 5000-20,000 eggs i.p. & ++ & + & - & \multirow{2}{*}{$\begin{array}{l}\text { Polarisation of immune response to Th2 } \\
\text { Increase in IL-4, reduction in Interferon (IFN)- } \gamma\end{array}$} & [46] \\
\hline & Schistosoma mansoni $5000-10,000$ eggs i.p./s.c. & ++ & ++ & - & & [46] \\
\hline \multirow{6}{*}{$\mathrm{MOG}_{35-55} \mathrm{C} 57 \mathrm{BL} / 6$ mice } & Schistosoma mansoni 5000-10,000 eggs i.p./ s.c. & ++ & ++ & - & \multirow{6}{*}{$\begin{array}{c}\text { Increase in IL-4, reduction in IFN- } \gamma \\
\text { Reduction of Th1 pro-inflammatory cytokines } \\
\text { Bystander attenuation of Th17 and Th1 responses by } \\
\text { means of Transforming growth factor (TGF)- } \beta \\
\text { Strong Th2 responses; Th1 and Th17 responses } \\
\text { suppressed } \\
\text { Anti-inflammatory cytokine environment leads to } \\
\text { reduced T cell activation } \\
\text { Reduction of IL-17A, IL-12 and promotion of } \\
\text { regulatory cytokines }\end{array}$} & [46] \\
\hline & Schistosoma mansoni 70 cercariae cutaneous & ++ & n.d. & n.d. & & [52] \\
\hline & Fasciola hepatica 10 metacercariae p.o. & ++ & n.d. & n.d. & & [33] \\
\hline & Trichinella pseudospiralis 200 larvae p.o. & ++ & n.d. & n.d. & & [53] \\
\hline & Taenia crassiceps 400 metacestodes i.p. & +++ & n.d. & n.d. & & [54] \\
\hline & Heligmosomoides polygyrus 200 larvae p.o. & n.d. & n.d. & ++ & & [55] \\
\hline MBP-EAE in Lewis rats & Strongyloides venezuelensis 4000 larvae s.c. & - & n.d. & n.d. & $\begin{array}{l}\text { No effect on disease course; The host may be resistant } \\
\text { to helminth infection }\end{array}$ & [45] \\
\hline \multirow{2}{*}{$\begin{array}{l}\text { Spinal cord homogenate } \\
\text { in Dark agouti (DA) rats }\end{array}$} & $\begin{array}{l}\text { Trichinella spiralis larvae Multiple doses by gastric } \\
\text { inoculation }\end{array}$ & $500 \& 1000++$ & n.d. & n.d. & \multirow{2}{*}{$\begin{array}{l}\text { Th2 response and regulatory response increase, also } \\
\text { increase in IL-10 } \\
\text { Th2 cytokine bias; anti-inflammatory responses likely } \\
\text { due to regulatory T cells }\end{array}$} & [56] \\
\hline & Trichinella spiralia Larvae p.o. & + & ++ & n.d. & & [57] \\
\hline
\end{tabular}

a PLP, proteolipid protein; MOG, myelin oligodendrocyte glycoprotein; MBP, myelin basic protein; ${ }^{\mathrm{b}}$ p.o., oral administration; i.p., intra-peritoneal injection; s.c., sub-cutaneous injection c The effect of helminth treatment on EAE severity, depending on the time at which helminth was administered is indicated by the following symbols: -, no effect; +, mild; ++, moderate; +++ , strong; n.d., not done. 
Table 2. Human clinical trials of live helminth infection as a therapeutic for Multiple Sclerosis.

\begin{tabular}{|c|c|c|c|c|c|c|c|}
\hline ClinicalTrialsgov ${ }^{a}$ & End Date & Subjects ${ }^{b}$ & Helminth Treatment ${ }^{c}$ & Clinical Evaluation Parameters ${ }^{d}$ & Results & Status ${ }^{e}$ & Ref. \\
\hline $\begin{array}{l}\text { HINT } 1 \\
\text { NCT00645749 }\end{array}$ & 2011 & 5 RRMS & $\begin{array}{l}2500 \text { TSO orally } \\
2 \text { weeks } \times 12 \text { weeks }\end{array}$ & $\begin{array}{l}\text { Number of new gadolinium } \\
\text { enhancing lesions on serial MRI } \\
\text { scans (monthly) }\end{array}$ & $\begin{array}{l}\text { Treatment was safe. No adverse effects. } \\
\text { No. of lesions fell from } 6.6 \text { at baseline to } 2 \text {. } \\
\text { Serum IL-4, IL-10 increased in } 4 \text { patients }\end{array}$ & C & [48] \\
\hline $\begin{array}{l}\text { TRIMS-A } 2010 \\
\text { NCT01006941 }\end{array}$ & 2011 & 10 RRMS & $\begin{array}{l}2,500 \text { TSO orally } \\
2 \text { weeks } \times 12 \text { weeks }\end{array}$ & $\begin{array}{l}\text { No. of new or enlarging T2 lesions, } \\
\text { no. of Gd enhancing lesions, volume } \\
\text { of T2 lesions }\end{array}$ & $\begin{array}{l}\text { Well tolerated; minor gastrointestinal } \\
\text { symptoms. No beneficial effect. }\end{array}$ & C & [58] \\
\hline Charite safety study & 2011 & 4 SPMS & $\begin{array}{l}2500 \text { TSO orally } \\
2 \text { weeks } \times 4 \text { weeks }\end{array}$ & $\begin{array}{l}\text { Immunological \& clinical parameters } \\
\text { were assessed }\end{array}$ & $\begin{array}{l}\text { Treatment was safe. } \\
\text { Lower Th1 \& increase in Th2 (IL-4) }\end{array}$ & C & [49] \\
\hline $\begin{array}{l}\text { TRIOMS } 2012 \\
\text { NCT01413243 }\end{array}$ & 2016 & 50 RRMS & $\begin{array}{l}2,500 \text { TSO orally } \\
2 \text { weeks } \times 12 \text { weeks }\end{array}$ & $\begin{array}{l}\text { Number of new gadolinium } \\
\text { enhancing lesions on serial MRI } \\
\text { scans; Vol of new T2 hyperintensive } \\
\text { in cerebral MRI }\end{array}$ & Terminated & $\mathrm{T}$ & [59] \\
\hline $\begin{array}{l}\text { WIRMS } 2011 \\
\text { NCT01470521 }\end{array}$ & 2016 & 72 RRMS & $\begin{array}{l}25 \text { live Necator americanus } \\
\text { dermally }\end{array}$ & $\begin{array}{l}\text { Number of new gadolinium } \\
\text { enhancing lesions on serial MRI } \\
\text { scans (at month 9), change in } \\
\text { expanded disability status scale }\end{array}$ & $\begin{array}{l}\text { Final results not released-expecting lower } \\
\text { number of lesions }\end{array}$ & C & [39] \\
\hline $\begin{array}{l}\text { HINT } 2 \\
\text { NCT00645749 }\end{array}$ & 2017 & 18 RRMS & $\begin{array}{l}2,500 \text { TSO orally } \\
2 \text { weeks } \times 10 \text { months }\end{array}$ & $\begin{array}{l}\text { Number of new gadolinium } \\
\text { enhancing lesions on serial MRI } \\
\text { scans (monthly) }\end{array}$ & $\begin{array}{l}\text { Safety confirmed. Interim MRI and } \\
\text { immunological measures positive. }\end{array}$ & $\mathrm{O}$ & {$[15,60]$} \\
\hline
\end{tabular}

${ }^{a}$ Clinicaltrials.gov website provides details of study design and updates on study progress. (NCT = national clinical trial; HINT = helminth-induced immunomodulation therapy; TRIMS-A = Trichuris suis ova therapy for multiple sclerosis—a safety study; TRIOMS = Trichuris suis ova in Recurrent Remittent Multiple Sclerosis and Clinically Isolated Syndrome;

WIRMS = worms for immune regulation of multiple sclerosis). ${ }^{b}$ The number and type of MS patients are listed (RRMS = relapsing-remitting MS; SPMS = secondary progressive MS).

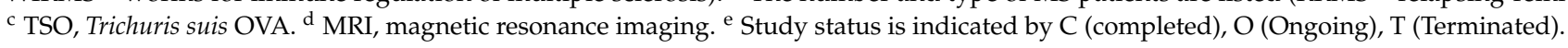




\section{Translating to the Clinic: Worms or Molecules?}

Collectively, the evidence gathered from natural endemic population studies, experimental animal work and human trials clearly support the possibility that helminths could be used as a treatment option for multiple sclerosis and provides a strong rationale that "worm therapy" is worth pursuing for the prevention or treatment of autoimmune disease.

However, the use of live parasites is not optimal. The compliance of patients is predicted to be generally poor, and this is largely attributable to negative attitudes associated with the concept of being infected with live pathogens [61]. In addition, the intake of live parasites (and, in some cases, the subsequent infection) has caused adverse side effects, at times even exacerbating pro-inflammatory conditions, due to the parasite's feeding and migratory activities [62,63].

The larval stages, which have been shown to be therapeutically beneficial in trials, must be produced in a mammalian host [28], so the possibility of a large scale production in compliance with good manufacturing practices (GMP) is limited and prohibits the mass scale production required for a truly global therapeutic. There is also a significant risk of contamination with other human pathogens. For example, the parasite N. americanus is harvested from the faeces of infected individuals. The use of the pig whipworm, T. suis, does not circumvent this problem, as there is a transferral risk of hepatitis E virus, which is often found in pigs and is pathogenic to humans [64]. Accordingly, the use of pathogen-free pigs would be required to ensure the absence of such infectious contaminants $[64,65]$. Additionally, using T. suis as a therapeutic agent requires the frequent intake of 2500 eggs, a dosing regimen with which many patients fail to comply. This is compounded with the fact that all ova might not hatch into active juveniles, thereby reducing the impact of the dose. Thus, the selection of the right helminth with the exact dosage and schedule of the treatment is difficult.

Finally, but most importantly, there is a lack of specificity with the use of live parasites. In populations endemically infected with helminths, Th1 and/or Th17 immune responses are compromised, which prevents the development of appropriate immune responses to bacterial/viral pathogens and vaccination [66]. Thus, the patient is effectively immune-compromised, just as he/she would be if prescribed immunosuppressive drugs. For individuals who are already immune compromised (such as children, the elderly, and pregnant women), treatment regimens using live helminth infections may be of greater risk than benefit [67-69].

A safer and more reliable alternative to live infection would be to identify the specific immune-modulatory molecules produced by helminth parasites. This approach would allow the precise mechanism(s) of action to be characterized, and their properties to be modified to increase therapeutic efficacy. In addition, synthetic proteins can be easily manufactured to therapeutic standard, and can be modified during synthesis into small molecule analogues to enhance stability, and to reduce undesirable immunogenicity and toxicity.

Within their mammalian hosts, helminth parasites secrete and excrete a mixture of molecules. These excretory/secretory (ES) products perform a number of biological functions to support the parasite's growth and reproduction, such as degradation of haemoglobin into essential nutrients and cleavage of collagen to facilitate migration through tissues. However, the ES products from many helminths also have the capacity to modulate host immune responses, analogous to live infection [70-73]. Furthermore, the delivery of ES products from a number of different helminths prevents or ameliorates the clinical signs of autoimmune disease in animal models of EAE (Table 3). In these experiments, all of the ES products prevented the development of disease when delivered during the pre-induction phase. Moreover, a strong protective effect was also observed when ES (in two experiments) was administered at or after the induction phase of disease. Consistent with the observation that intraperitoneal delivery of S. mansoni eggs to animals afforded protection from EAE (Table 1), the administration of secreted egg antigens (SEA) derived from the same parasite also suppressed the progression of disease (Table 3) [74].

Based on this evidence, a typical process for drug discovery would involve a rational search through the contents of SEA to identify the key molecule that is mediating beneficial immune 
modulation to prevent disease development. However, SEA is the soluble products derived from the homogenate of eggs and therefore contains numerous components that are naturally secreted from eggs during infections, but also molecules that are normally held within the structure of the egg. Proteomic analysis using two-dimensional electrophoresis of SEA has identified $>1000$ proteins [75]; thus, identifying the singular components that may be mediating protection from EAE presents a challenging task.

The clinical signs of EAE were also reduced in mice treated with the ES derived from Fasciola hepatica. Unlike SEA, this preparation contains only the products that are naturally secreted by the adult worm and therefore is more likely to contain the proteins that are secreted during infection and which interact with the cells of the host immune response. Furthermore, in contrast to the complexity of SEA, proteomic analysis of $F$. hepatica ES has identified 160 proteins, $67 \%$ of which are cysteine proteases [76]. 
Table 3. Experimental studies assessing the protective effect of helminth soluble products in animal models of EAE.

\begin{tabular}{|c|c|c|c|c|c|}
\hline \multirow{2}{*}{ Animal Model } & \multirow{2}{*}{ Helminth Treatment ${ }^{a}$} & \multicolumn{2}{|c|}{ Time Point of Administration ${ }^{b}$} & \multirow{2}{*}{ Mechanism of Protection } & \multirow{2}{*}{ Ref. } \\
\hline & & Pre-Induction & Induction & & \\
\hline \multirow{6}{*}{$\begin{array}{l}\mathrm{MOG}_{35-55} \text { in } \mathrm{C} 57 \mathrm{BL} / 6 \\
\text { mice }\end{array}$} & $\begin{array}{c}\text { Schistosoma japonicum SEA } \\
100 \mu \mathrm{g} \text { i.p. once a week for } 4 \text { weeks }\end{array}$ & + & ++ & Th2 environment established. & [74] \\
\hline & $\begin{array}{c}\text { Trichuris suis SP } \\
100 \mu \mathrm{g} \text { i.p. once a week for } 4 \text { weeks }\end{array}$ & ++ & n.d. & $\begin{array}{l}\text { Unknown. In vitro suppression of pro-inflammatory } \\
\text { dendritic cells }\end{array}$ & [77] \\
\hline & $\begin{array}{c}\text { Trichuris spiralis SP } \\
100 \mu \mathrm{g} \text { i.p. once a week for } 4 \text { weeks }\end{array}$ & ++ & n.d. & $\begin{array}{l}\text { Unknown. In vitro suppression of pro-inflammatory } \\
\text { dendritic cells }\end{array}$ & [77] \\
\hline & $\begin{array}{c}\text { Trichuris suis ESP } \\
250 \mu \mathrm{g} \text { i.p. alternate days over } 22 \text { days }\end{array}$ & n.d. & ++ & Reduced number of splenic Th1 and Th17 cells & [78] \\
\hline & $\begin{array}{c}\text { F. hepatica ESP } \\
\text { Five or Six daily doses of } 50 \mu \mathrm{g} / \text { dose i.p. }\end{array}$ & + & ++ & Production of innate type 2 cytokines IL- 5 and IL- 33 . & [79] \\
\hline & $\begin{array}{c}\text { Taenia Crassiceps ESP } \\
250 \mu \text { i.p. alternate days } \times 7 \text { times }\end{array}$ & n.d. & +++ & $\begin{array}{l}\text { Induction of Th2. Suppression of Tumour Necrosis } \\
\text { Factor (TNF) and IL-17. Redirected cell migration } \\
\text { from the central nervous system to peritoneal cavity }\end{array}$ & [80] \\
\hline $\begin{array}{l}\text { Spinal cord homogenate } \\
\text { in DA rats }\end{array}$ & $\begin{array}{c}\text { Trichinella spiralis larvae ESP } \\
\text { Multiple doses of soluble products i.p. }\end{array}$ & ++ & n.d. & $\begin{array}{l}\text { Strong Th2-type response and increased proportion of } \\
\text { CD4+CD25-Foxp3+ regulatory cells }\end{array}$ & [81] \\
\hline
\end{tabular}

a SEA, Schistosome egg antigen; SP, secretory products; ESP, excretory/secretory products; i.p., intra-peritoneal injection. ${ }^{\mathrm{b}}$ The effect of helminth treatment on EAE severity, depending on the time at which helminth was administered is indicated by the following symbols: +, mild; ++, moderate; n.d., not done. 


\section{The Peptide FhHDM-1, Secreted by Fasciola hepatica, Shows Therapeutic Efficacy in EAE}

F. hepatica, commonly known as the liver fluke, has adapted to long-term survival within its mammalian hosts, living up to 20 years in some instances [82,83]. Additionally, F. hepatica exhibits a widespread geographical distribution, and infects the greatest variety of mammals of all helminth parasites [84,85]. Not only does this imply a superior adaptation, as compared to other helminth parasites, such as $N$. Americanus and T. suis, which have adapted to infect only a single host, but it also suggests that Fasciola parasites have evolved universal processes of invasion, virulence and immune modulation.

The infection pathway of $F$. hepatica begins within the mammalian host after the ingestion of metacercariae, which are the encysted larval form of the worm (Figure 1). Upon reaching the acidic environment of the gastrointestinal tract, immature flukes hatch, and these newly excysted juvenile (NEJ) flukes migrate through the gut wall to enter the peritoneal cavity. The NEJ flukes continue to burrow through to the liver, reaching the bile ducts 10-12 weeks after ingestion. Within the bile ducts, the NEJ flukes mature into adult forms, whose primary activities are feeding on blood by puncturing holes in the bile duct wall, and production of eggs [82]. The mature adults are obligate blood feeders and secrete copious amounts of cysteine proteases (FhCL) to effectively digest blood proteins, particularly haemoglobin, to provide sufficient nutrients required for egg production [86]. Related to this activity is the production of the anti-oxidant peroxiredoxin (FhPrx), which detoxifies the reactive oxygen generated by cellular metabolism [86,87], and the production of FhHDM-1, a peptide that interacts with heme, a toxic by product of haemoglobin digestion [88]. In addition to these activities to support the parasite's life cycle, these three proteins have also been shown to act as potent immune modulators, specifically inhibiting the activation of pro-inflammatory innate immune responses [89-93].

A

B

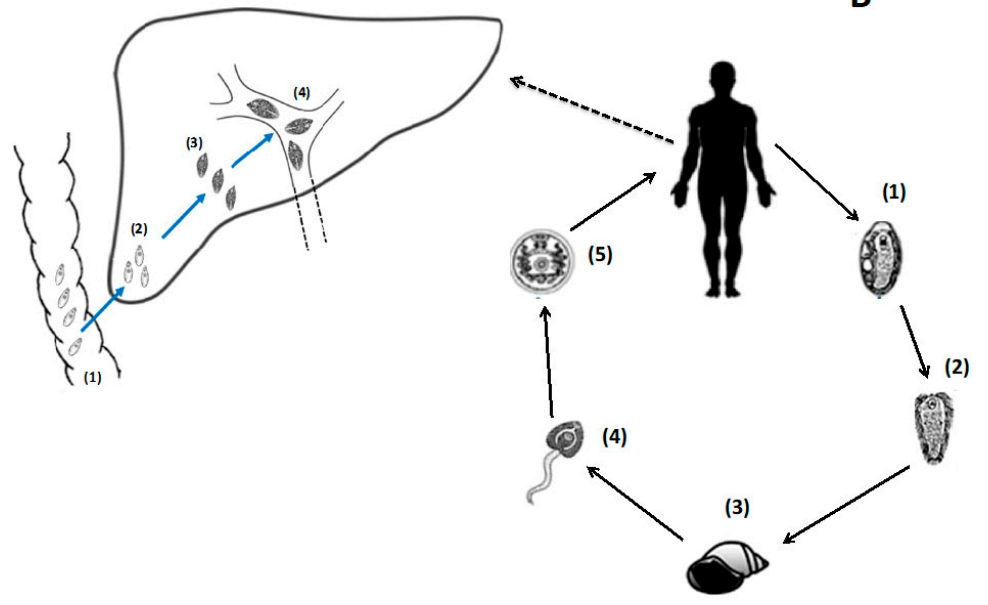

Figure 1. Fasciola hepatica lifecycle. Graphical representation of the F. hepatica lifecycle (adapted from [82]). (A1) parasite excyst in the intestine of the mammalian host, releasing newly excysted juveniles (NEJ) that migrate across the intestinal wall, through the peritoneal cavity to the liver (A2). NEJ migrate through the liver parenchyma, increasing in size to juvenile flukes as they migrate into the bile ducts (A3), where they grow and develop into fully mature adults (A4); (B1) eggs are released in the faeces and develop on vegetation; (B2) a single miracidium hatches from each embryonated egg and then (B3) infects the intermediate snail host (Galba truncatula); (B4) within the snail, the parasite develops through the sporocyst, rediae and cercariae lifecycle stages. Cercariae are released from the snail and (B5) encyst on vegetation as dormant metacercariae, which are subsequently ingested by the definitive host. 
Considering their capacity to alter inflammatory immune responses, we assessed the therapeutic efficacy of recombinant forms of the three most abundant molecules of $F$. hepatica ES, FhPrx, FhCL1 and FhHDM-1 in an animal model of relapsing remitting EAE. Despite their evident immune modulating activity, neither FhPrx (Donnelly et al., unpublished data) nor FhCL1 [94] prevented disease development. However, a short time course of treatment with FhHDM-1 significantly reduced the clinical signs of EAE [94], which was associated with the absence of immune cell infiltrates into the CNS. These observations suggested that, within the ES of the adult F. hepatica, FhHDM-1 may be the sole molecule with potential as an immune therapeutic.

Unexpectedly, FhHDM-1 treatment of mice did not alter the profile of cytokines produced by $\mathrm{T}$ cells in response to autoantigen. Unlike infection and the administration of $\mathrm{ES}$, Th1 cytokines were evident and there was no significant switch to a type 2 immune response. However, after parenteral administration, the FhHDM-1 peptide interacted with macrophages and reduced their capacity to secrete pro-inflammatory cytokines. Thus, it has been hypothesized that the inhibition of innate pro-inflammatory immune responses, which are central to the development of autoimmunity in EAE and MS, prevented the trafficking of autoreactive lymphocytes from the periphery to the site of autoimmunity and thus prevented tissue destruction.

\section{Conclusions}

The studies discussed here represent a significant body of evidence that proteins secreted by helminth parasites offer a unique resource for the discovery of anti-inflammatory drugs. The specific finding that a single parasite secreted protein, FhHDM-1, can suppress the pathology associated with EAE, although preliminary, suggests that understanding the mode of action of this parasite protein may provide a novel starting point in the development of safe effective drugs for treatment of human MS. The efficacy of parasite-derived molecules has been fine-tuned over millennia of co-evolution with humans, suggesting that the pharmacological activity of these proteins has already been optimized over time by nature. Therefore, exploiting the excretory secretory products from helminth parasites offers the potential for drug treatments that are far superior to current biologicals whose widespread use is limited by a lack of specificity and a range of adverse side effects.

Acknowledgments: The work was supported by the Multiple Sclerosis Research Australia (15-033; to Sheila Donnelly and Judith Greer), a University of Queensland Research Scholarship (to Aakanksha Dixit), and an Australian Commonwealth Government Department of Industry Australian Postgraduate Award Scholarship (to Akane Tanaka).

Author Contributions: Aakanksha Dixit searched and reviewed literature, drafted and revised the manuscript; Akane Tanaka searched and reviewed literature and revised the manuscript; Sheila Donnelly and Judith M. Greer designed and formulated the review theme, viewed the literature, revised and finalized the manuscript.

Conflicts of Interest: The authors declare no conflict of interest. 


\section{Abbreviations}

\begin{tabular}{|c|c|}
\hline MS & Multiple sclerosis \\
\hline GWAS & Genome wide association studies \\
\hline ILC2 & Type 2 Innate lymphoid cells \\
\hline IL & Interleukin \\
\hline Th & T helper \\
\hline DC & Dendritic cell \\
\hline Treg & T-regulatory cell \\
\hline TGF- $\beta$ & Transforming growth factor-beta \\
\hline EAE & Experimental autoimmune encephalomyelitis \\
\hline CNS & Central nervous system \\
\hline MOG & Myelin oligodendrocyte glycoprotein \\
\hline PLP & Proteolipid protein \\
\hline MBP & Myelin basic protein \\
\hline po & Oral administration \\
\hline ip & Intraperitoneal injection \\
\hline Sc & Subcutaneous injection \\
\hline IFN & Interferon \\
\hline DA & Dark Agouti \\
\hline TSO & Trichuris suis ova \\
\hline RRMS & Relapsing remitting multiple sclerosis \\
\hline SPMS & Secondary progressive multiple sclerosis \\
\hline MRI & Magnetic resonance imaging \\
\hline NCT & National Clinical Trial \\
\hline HINT & Helminth-induced immunomodulation therapy \\
\hline TRIMS-A & $\begin{array}{l}\text { Trichuris suis ova therapy for multiple sclerosis-a } \\
\text { safety study }\end{array}$ \\
\hline TRIOMS & $\begin{array}{l}\text { Trichuris suis ova in recurrent remittent multiple } \\
\text { sclerosis and clinically isolated syndrome }\end{array}$ \\
\hline WIRMS & Worms for immune regulation of multiple sclerosis \\
\hline GMP & Good manufacturing practices \\
\hline SEA & Schistosoma egg antigen \\
\hline ESP & Excretory secretory products \\
\hline TNF & Tumour necrosis factor \\
\hline NEJ & Newly excysted juveniles \\
\hline FhCL & Fasciola hepatica cathepsin L \\
\hline FhPrx & Fasciola hepatica peroxiredoxin \\
\hline FhHDM-1 & Fasciola hepatica helminth defense molecule \\
\hline
\end{tabular}

\section{References}

1. Sawcer, S. The major cause of multiple sclerosis is environmental: Genetics has a minor role-no. Mult. Scler. 2011, 17, 1174-1175. [CrossRef] [PubMed]

2. Taylor, B.V. The major cause of multiple sclerosis is environmental: Genetics has a minor role-yes. Mult. Scler. 2011, 17, 1171-1173. [CrossRef] [PubMed]

3. Gourraud, P.A.; Harbo, H.F.; Hauser, S.L.; Baranzini, S.E. The genetics of multiple sclerosis: An up-to-date review. Immunol. Rev. 2012, 248, 87-103. [CrossRef] [PubMed]

4. Correale, J.; Farez, M.F.; Gaitán, M.I. Environmental factors influencing multiple sclerosis in Latin America. Mult. Scler. J. Exp. Transl. Clin. 2017, 3, 2055217317715049. [CrossRef] [PubMed]

5. Ebers, G.C.; Bulman, D.E.; Sadovnik, A.D.; Paty, D.W.; Warren, S.; Hader, W.; Murray, T.J.; Seland, T.P.; Duquette, P.; Grey, T. A population-based study of multiple sclerosis in twins. N. Engl. J. Med. 1986, 315, 1638-1642. [CrossRef] [PubMed]

6. Bach, J.F. The effect of infections on susceptibility to autoimmune and allergic diseases. N. Engl. J. Med. 2002, 347, 911-920. [CrossRef] [PubMed] 
7. Bilbo, S.D.; Wray, G.A.; Perkins, S.E.; Parker, W. Reconstitution of the human biome as the most reasonable solution for epidemics of allergic and autoimmune diseases. Med. Hypotheses 2011, 77, 494-504. [CrossRef] [PubMed]

8. Cooke, A. Infection and autoimmunity. Blood Cells Mol. Dis. 2009, 42, 105-107. [CrossRef] [PubMed]

9. Okada, H.; Kuhn, C.; Feillet, H.; Bach, J.F. The 'hygiene hypothesis' for autoimmune and allergic diseases: An update. Clin. Exp. Immunol. 2010, 160,1-9. [CrossRef] [PubMed]

10. Orton, S.M.; Ramagopalan, S.V.; Brocklebank, D.; Herrera, B.M.; Dyment, D.A.; Yee, I.M.; Sadovnick, A.D.; Ebers, G.C. Effect of immigration on multiple sclerosis sex ratio in Canada: The Canadian Collaborative Study. J. Neurol. Neurosurg. Psychiatry 2010, 81, 31-36. [CrossRef] [PubMed]

11. McLeod, J.G.; Hammond, S.R.; Kurtzke, J.F. Migration and multiple sclerosis in United Kingdom and Ireland immigrants to Australia: A reassessment. II. Characteristics of early (pre-1947) compared to later migrants. J. Neurol. 2012, 259, 684-693. [CrossRef] [PubMed]

12. Ascherio, A.; Munger, K.L. Environmental risk factors for multiple sclerosis. Part I: The role of infection. Ann. Neurol. 2007, 61, 288-299. [CrossRef] [PubMed]

13. Ascherio, A.; Munger, K.L. Environmental risk factors for multiple sclerosis. Part II: Noninfectious factors. Ann. Neurol. 2007, 61, 504-513. [CrossRef] [PubMed]

14. Taylor, B.V.; Lucas, R.M.; Dear, K.; Kilpatrick, T.J.; Pender, M.P.; van der Mei, I.A.; Chapman, C.; Coulthard, A.; Dwyer, T.; McMichael, A.J.; et al. Latitudinal variation in incidence and type of first central nervous system demyelinating events. Mult. Scler. 2010, 16, 398-405. [CrossRef] [PubMed]

15. Fleming, J.O. Helminth therapy and multiple sclerosis. Int. J. Parasitol. 2013, 43, 259-274. [CrossRef] [PubMed]

16. Correale, J.; Gaitán, M.I. Multiple sclerosis and environmental factors: The role of vitamin D, parasites, and Epstein-Barr virus infection. Acta Neurol. Scand. 2015, 132, 46-55. [CrossRef] [PubMed]

17. Olsson, T.; Barcellos, L.F.; Alfredsson, L. Interactions between genetic, lifestyle and environmental risk factors for multiple sclerosis. Nat. Rev. Neurol. 2017, 13, 25-36. [CrossRef] [PubMed]

18. Zaccone, P.; Fehervari, Z.; Phillips, J.M.; Dunne, D.W.; Cooke, A. Parasitic worms and inflammatory diseases. Parasite Immunol. 2006, 28, 515-523. [CrossRef] [PubMed]

19. Cabre, P.; Signate, A.; Olindo, S.; Merle, H.; Caparros-Lefebvre, D.; Béra, O.; Smadja, D. Role of return migration in the emergence of multiple sclerosis in the French West Indies. Brain 2005, 128, 2899-2910. [CrossRef] [PubMed]

20. Fleming, J.O.; Cook, T.D. Multiple sclerosis and the hygiene hypothesis. Neurology 2006, 67, $2085-2086$. [CrossRef] [PubMed]

21. Correale, J.; Farez, M. The impact of parasite infections on the course of multiple sclerosis. J. Neuroimmunol. 2011, 233, 6-11. [CrossRef] [PubMed]

22. Hotez, P.J.; Brindley, P.J.; Bethony, J.M.; King, C.H.; Pearce, E.J.; Jacobson, J. Helminth infections: The great neglected tropical diseases. J. Clin. Investig. 2008, 118, 1311-1321. [CrossRef] [PubMed]

23. Cox, F.E. History of human parasitology. Clin. Microbiol. Rev. 2002, 15, 595-612. [CrossRef] [PubMed]

24. Jackson, J.A.; Friberg, I.M.; Little, S.; Bradley, J.E. Review series on helminths, immune modulation and the hygiene hypothesis: Immunity against helminths and immunological phenomena in modern human populations: Coevolutionary legacies? Immunology 2009, 126, 18-27. [CrossRef] [PubMed]

25. Finkelman, F.D.; Shea-Donohue, T.; Morris, S.C.; Gildea, L.; Strait, R.; Madden, K.B.; Schopf, L.; Urban, J.F. Interleukin-4- and interleukin-13- mediated host protection against intestinal nematode parasites. Immunol. Rev. 2004, 201, 139-155. [CrossRef] [PubMed]

26. Jenkins, S.J.; Allen, J.E. Similarity and diversity in macrophage activation by nematodes, trematodes, and cestodes. J. Biomed. Biotechnol. 2010, 2010, 262609. [CrossRef] [PubMed]

27. Anthony, R.M.; Rutitzky, L.I.; Urban, J.F.; Stadecker, M.J.; Gause, W.C. Protective immune mechanisms in helminth infection. Nat. Rev. Immunol. 2007, 7, 975-987. [CrossRef] [PubMed]

28. McSorley, H.J.; Hewitson, J.P.; Maizels, R.M. Immunomodulation by helminth parasites: Defining mechanisms and mediators. Int. Jnl. Parasitol. 2013, 43, 301-310. [CrossRef] [PubMed]

29. Fallon, P.G.; Ballantyne, S.J.; Mangan, N.E.; Barlow, J.L.; Dasvarma, A.; Hewett, D.R.; McIlgorm, A.; Jolin, H.E.; McKenzie, A.N. Identification of an interleukin (IL)-25-dependent cell population that provides IL-4, IL-5, and IL-13 at the onset of helminth expulsion. J. Exp. Med. 2006, 203, 1105-1116. [CrossRef] [PubMed] 
30. Howitt, M.R.; Lavoie, S.; Michaud, M.; Blum, A.M.; Tran, S.V.; Weinstock, J.V.; Gallini, C.A.; Redding, K.; Margolskee, R.F.; Osborne, L.C.; et al. Tuft cells, taste-chemosensory cells, orchestrate parasite type 2 immunity in the gut. Science 2016, 351, 1329-1333. [CrossRef] [PubMed]

31. Klose, C.S.; Artis, D. Innate lymphoid cells as regulators of immunity, inflammation and tissue homeostasis. Nat. Immunol. 2016, 17, 765-774. [CrossRef] [PubMed]

32. Mosser, D.M.; Edwards, J.P. Exploring the full spectrum of macrophage activation. Nat. Rev. Immunol. 2008, 8, 958-969. [CrossRef] [PubMed]

33. Walsh, K.P.; Brady, M.T.; Finlay, C.M.; Boon, L.; Mills, K.H. Infection with a helminth parasite attenuates autoimmunity through TGF- $\beta$-mediated suppression of Th17 and Th1 responses. J. Immunol. 2009, 183, 1577-1586. [CrossRef] [PubMed]

34. Gause, W.C.; Wynn, T.A.; Allen, J.E. Type 2 immunity and wound healing: Evolutionary refinement of adaptive immunity by helminths. Nat. Rev. Immunol. 2013, 13, 607-614. [CrossRef] [PubMed]

35. Allen, J.E.; Wynn, T.A. Evolution of Th2 immunity: A rapid repair response to the tissue destructive pathogens. PLoS Pathog. 2011, 7, e1002003. [CrossRef] [PubMed]

36. Fumagalli, M.; Pozzoli, U.; Cagliani, R.; Comi, G.P.; Riva, S.; Clerici, M.; Bresolin, N.; Sironi, M. Parasites represent a major selective force for interleukin genes and shape the genetic predisposition to autoimmune conditions. J. Exp. Med. 2009, 206, 1395-1408. [CrossRef] [PubMed]

37. Maizels, R.M. Parasite immunomodulation and polymorphisms of the immune system. J Biol. $2009,8,62$. [CrossRef] [PubMed]

38. Allen, J.E.; Maizels, R.M. Diversity and dialogue in immunity to helminths. Nat. Rev. Immunol. 2011, 11, 375-388. [CrossRef] [PubMed]

39. Edwards, L.J.; Constantinescu, C.S. Parasite immunomodulation in autoimmune disease: Focus on multiple sclerosis. Expert. Rev. Clin. Immunol. 2009, 5, 487-489. [CrossRef] [PubMed]

40. Hasseldam, H.; Hansen, C.S.; Johansen, F.F. Immunomodulatory effects of helminths and protozoa in multiple sclerosis and experimental autoimmune encephalomyelitis. Parasite Immunol. 2013, 35, 103-108. [CrossRef] [PubMed]

41. Tanasescu, R.; Constantinescu, C.S. Helminth Therapy for MS. Curr. Top. Behav. Neurosci. 2015, 26, 195-220. [PubMed]

42. Peón, A.N.; Terrazas, L.I. Immune-Regulatory Mechanisms of Classical and Experimental Multiple Sclerosis Drugs: A Special Focus on Helminth-Derived Treatments. Curr. Med. Chem. 2016, 23, 1152-1170. [CrossRef] [PubMed]

43. Filyk, H.A.; Osborne, L.C. The Multibiome: The Intestinal Ecosystem's Influence on Immune Homeostasis, Health, and Disease. EBioMedicine 2016, 13, 46-54. [CrossRef] [PubMed]

44. Kuerten, S.; Lehmann, P.V. The immune pathogenesis of experimental autoimmune encephalomyelitis: Lessons learned for multiple sclerosis? J. Interferon Cytokine Res. 2011, 31, 907-916. [CrossRef] [PubMed]

45. Chiuso-Minicucci, F.; Van, D.B.; Zorzella-Pezavento, S.F.; Peres, R.S.; Ishikawa, L.L.; Rosa, L.C.; França, T.G.; Turato, W.M.; Amarante, A.F.; Sartori, A. Experimental autoimmune encephalomyelitis evolution was not modified by multiple infections with Strongyloides venezuelensis. Parasite Immunol. 2011, 33, 303-308. [CrossRef] [PubMed]

46. Sewell, D.; Qing, Z.; Reinke, E.; Elliot, D.; Weinstock, J.; Sandor, M.; Fabry, Z. Immunomodulation of experimental autoimmune encephalomyelitis by helminth ova immunization. Int. Immunol. 2003, 15, 59-69. [CrossRef] [PubMed]

47. Correale, J.; Farez, M. Association between parasite infection and immune responses in multiple sclerosis. Ann. Neurol. 2007, 61, 97-108. [CrossRef] [PubMed]

48. Fleming, J.O.; Isaak, A.; Lee, J.E.; Luzzio, C.C.; Carrithers, M.D.; Cook, T.D.; Field, A.S.; Boland, J.; Fabry, Z. Probiotic helminth administration in relapsing-remitting multiple sclerosis: A phase 1 study. Mult. Scler. 2011, 17, 743-754. [CrossRef] [PubMed]

49. Benzel, F.; Erdur, H.; Kohler, S.; Frentsch, M.; Thiel, A.; Harms, L.; Wandinger, K.P.; Rosche, B. Immune monitoring of Trichuris suis egg therapy in multiple sclerosis patients. J. Helminthol. 2012, 86, 339-347. [CrossRef] [PubMed]

50. Broadhurst, M.J.; Leung, J.M.; Kashyap, V.; McCune, J.M.; Mahadevan, U.; McKerrow, J.H.; Loke, P. IL-22+ CD4+ $\mathrm{T}$ cells are associated with therapeutic Trichuris trichiura infection in an ulcerative colitis patient. Sci. Transl. Med. 2010, 2, 60ra88. [CrossRef] [PubMed] 
51. Gaze, S.; McSorley, H.J.; Daveson, J.; Jones, D.; Bethony, J.M.; Oliveira, L.M.; Speare, R.; McCarthy, J.S.; Engwerda, C.R.; Croese, J.; et al. Characterising the mucosal and systemic immune responses to experimental human hookworm infection. PLoS Pathog. 2012, 8, e1002520. [CrossRef] [PubMed]

52. La Flamme, A.C.; Ruddenklau, K.; Backstrom, B.T. Schistosomiasis decreases central nervous system inflammation and alters the progression of experimental autoimmune encephalomyelitis. Infect. Immun. 2003, 71, 4996-5004. [CrossRef] [PubMed]

53. Wu, Z.; Nagano, I.; Asanom, K.; Takahashim, Y. Infection of non-encapsulated species of Trichinella ameliorates experimental autoimmune encephalomyelitis involving suppression of Th17 and Th1 response. Parasitol. Res. 2010, 107, 1173-1188. [CrossRef] [PubMed]

54. Reyes, J.L.; Espinoza-Jiménez, A.F.; González, M.I.; Verdin, L.; Terrazas, L.I. Taenia crassiceps infection abrogates experimental autoimmune encephalomyelitis. Cell Immunol. 2011, 267, 77-87. [CrossRef] [PubMed]

55. Donskow-Lysoniewska, K.; Krawczak, K.; Doligalska, M. Heligmosomoides polygyrus: EAE remission is correlated with different systemic cytokine profiles provoked by L4 and adult nematodes. Exp. Parasitol. 2012, 132, 243-248. [CrossRef] [PubMed]

56. Gruden-Movsesijan, A.; Ilic, N.; Mostarica-Stojkovic, M.; Stosic-Grujicic, S.; Milic, M.; Sofronic-Milosavljevic, L. Trichinella spiralis: Modulation of experimental autoimmune encephalomyelitis in DA rats. Exp. Parasitol. 2008, 118, 641-647. [CrossRef] [PubMed]

57. Gruden-Movsesijan, A.; Ilic, N.; Mostarica-Stojkovic, M.; Stosic-Grujicic, S.; Milic, M.; Sofronic-Milosavljevic, L. Mechanisms of modulation of experimental autoimmune encephalomyelitis by chronic Trichinella spiralis infection in Dark Agouti rats. Parasite Immunol. 2010, 32, 450-459. [CrossRef] [PubMed]

58. Voldsgaard, A.; Bager, P.; Garde, E.; Åkeson, P.; Leffers, A.M.; Madsen, C.G.; Kapel, C.; Roepstorff, A.; Thamsborg, S.M.; Melbye, M.; et al. Trichuris suis ova therapy in relapsing multiple sclerosis is safe but without signals of beneficial effect. Mult. Scler. 2015, 21, 1723-1729. [CrossRef] [PubMed]

59. Rosche, B.; Wernecke, K.D.; Ohlraun, S.; Dörr, J.M.; Paul, F. Trichuris suis ova in relapsing-remitting multiple sclerosis and clinically isolated syndrome (TRIOMS): Study protocol for a randomized controlled trial. Trials 2013, 14, 112. [CrossRef] [PubMed]

60. Fleming, J.O.; Weinstock, J.V. Clinical trials of helminth therapy in autoimmune diseases: Rationale and findings. Parasite Immunol. 2015, 37, 277-292. [CrossRef] [PubMed]

61. Khan, A.R.; Fallon, P.G. Helminth therapies: Translating the unknown unknowns into known knowns. Int. J. Parasitol. 2013, 43, 293-299. [CrossRef] [PubMed]

62. Ruyssers, N.E.; De Winter, B.Y.; De Man, J.G.; Loukas, A.; Herman, A.G.; Pelckmans, P.A.; Moreels, T.G. Worms and the treatment of inflammatory bowel disease: Are molecules the answer? Clin. Dev. Immunol. 2008, 567314. [CrossRef] [PubMed]

63. Briggs, N.; Weatherhead, J.; Sastry, K.J.; Hotez, P.J. The Hygiene Hypothesis and Its Inconvenient Truths about Helminth Infections. PLoS Negl. Trop. Dis. 2016, 10, e0004944. [CrossRef] [PubMed]

64. Jouvin, M.H.; Kinet, J.P. Trichuris suis ova: Testing a helminth-based therapy as an extension of the hygiene hypothesis. J. Allergy Clin. Immunol. 2012, 130, 3-10. [CrossRef] [PubMed]

65. Summers, R.W.; Elliott, D.E.; Urban, J.F.; Thompson, R.; Weinstock, J.V. Trichuris suis therapy in Crohn's disease Gut 2005, 54, 87-90. Gut 2005, 54, 87-90. [CrossRef] [PubMed]

66. Maizels, R.M.; Yazdanbakhsh, M. T-cell regulation in helminth parasite infections: Implications for inflammatory diseases. Chem. Immunol. Allergy 2008, 94, 112-123. [PubMed]

67. Farah, I.O.; Langoi, D.; Nyaundi, J.; Hau, J. Schistosome-induced pathology is exacerbated and Th2 polarization is enhanced during pregnancy. In Vivo 2007, 21, 599-602. [PubMed]

68. Mejia, R.; Nutman, T.B. Screening, prevention, and treatment for hyperinfection syndrome and disseminated infections caused by Strongyloides stercoralis. Curr. Opin. Infect. Dis. 2012, 25, 458-463. [CrossRef] [PubMed]

69. Wammes, L.J.; Mpairwe, H.; Elliott, A.M.; Yazdanbakhsh, M. Helminth therapy or elimination: Epidemiological, immunological, and clinical considerations. Lancet Infect. Dis. 2014, 14, 1150-1162. [CrossRef]

70. Johnston, M.J.; MacDonald, J.A.; McKay, D.M. Parasitic helminths: A pharmacopeia of anti-inflammatory molecules. Parasitology 2009, 136, 125-147. [CrossRef] [PubMed]

71. Hewitson, J.P.; Grainger, J.R.; Maizels, R.M. Helminth immunoregulation: The role of parasite secreted proteins in modulating host immunity. Mol. Biochem. Parasitol. 2009, 167, 1-11. [CrossRef] [PubMed] 
72. Harnett, W.; Harnett, M.M. Helminth-derived immunomodulators: Can understanding the worm produce the pill? Nat. Rev. Immunol. 2010, 10, 278-284. [CrossRef] [PubMed]

73. Ditgen, D.; Anandarajah, E.M.; Meissner, K.A.; Brattig, N.; Wrenger, C.; Liebau, E. Harnessing the Helminth Secretome for Therapeutic Immunomodulators. Bio. Med. Res. Int. 2014, 2014, 964350. [CrossRef] [PubMed]

74. Zheng, X.; Hu, X.; Zhou, G.; Lu, Z.; Qiu, W.; Bao, J.; Dai, Y. Soluble egg antigen from Schistosoma japonicum modulates the progression of chronic progressive experimental autoimmune encephalomyelitis via Th2-shift response. J. Neuroimmunol. 2008, 194, 107-114. [CrossRef] [PubMed]

75. Mathieson, W.; Wilson, R.A. A comparative proteomic study of the undeveloped and developed Schistosoma mansoni egg and its contents: The miracidium, hatch fluid and secretions. Int. J. Parasitol. 2010, 40, 617-628. [CrossRef] [PubMed]

76. Robinson, M.W.; Menon, R.; Donnelly, S.M.; Dalton, J.P.; Ranganathan, S. An integrated transcriptomics and proteomics analysis of the secretome of the helminth pathogen Fasciola hepatica: Proteins associated with invasion and infection of the mammalian host. Mol. Cell Proteom. 2009, 8, 1891-1907. [CrossRef] [PubMed]

77. Kuijk, L.M.; Klaver, E.J.; Kooij, G.; van der Pol, S.M.; Heijnen, P.; Bruijns, S.C.; Kringel, H.; Pinelli, E.; Kraal, G.; de Vries, H.E.; et al. Soluble helminth products suppress clinical signs in murine experimental autoimmune encephalomyelitis and differentially modulate human dendritic cell activation. Mol. Immunol. 2012, 51, 210-218. [CrossRef] [PubMed]

78. Hansen, C.S.; Hasseldam, H.; Bacher, I.H.; Thamsborg, S.M.; Johansen, F.F.; Kringel, H. Trichuris suis secrete products that reduce disease severity in a multiple sclerosis model. Acta Parasitol. 2017, 62, 22-28. [CrossRef] [PubMed]

79. Finlay, C.M.; Stefanskam, A.M.; Walsh, K.P.; Kelly, P.J.; Boon, L.; Lavelle, E.C.; Walsh, P.T.; Mills, K.H. Helminth products protect against autoimmunity via innate type 2 cytokines IL- 5 and IL-33, which promote eosinophilia. J. Immunol. 2016, 196, 703-714. [CrossRef] [PubMed]

80. Peón, A.N.; Ledesma-Soto, Y.; Olguín, J.E.; Bautista-Donis, M.; Sciutto, E.; Terrazas, L.I. Helminth products potently modulate experimental autoimmune encephalomyelitis by downregulating neuroinflammation and promoting a suppressive microenvironment. Mediators Inflamm. 2017, 2017. [CrossRef] [PubMed]

81. Radovic, I.; Gruden-Movsesijan, A.; Ilic, N.; Cvetkovic, J.; Mojsilovic, S.; Devic, M.; Sofronic-Milosavljevic, L. Immunomodulatory effects of Trichinella spiralis-derived excretory-secretory antigens. Immunol. Res. 2015, 61, 312-325. [CrossRef] [PubMed]

82. Andrews, S.J. The life-cycle of Fasciola hepatica. In Fasciolosis; Dalton, J.P., Ed.; CAB International: Oxford, UK, 1999; pp. 1-29.

83. Mas-Coma, S.; Valero, M.A.; Bargues, M.D. Fasciola, lymnaeids and human fascioliasis, with a global overview on disease transmission, epidemiology, evolutionary genetics, molecular epidemiology and control. Adv. Parasitol. 2009, 69, 41-146. [PubMed]

84. Garcia, H.H.; Moro, P.L.; Schantz, P.M. Zoonotic helminth infections of humans: Echinococcosis, cysticercosis and fascioliasis. Curr. Opin. Infect. Dis. 2007, 20, 489-494. [CrossRef] [PubMed]

85. Mas-Coma, S.; Bargues, M.D.; Valero, M.A. Fascioliasis and other plant-borne trematode zoonoses. Int. J. Parasitol. 2005, 35, 1255-1278. [CrossRef] [PubMed]

86. Cwiklinski, K.; Dalton, J.P.; Dufresne, P.J.; La Course, J.; Williams, D.J.; Hodgkinson, J.; Paterson, S. The Fasciola hepatica genome: Gene duplication and polymorphism reveals adaptation to the host environment and the capacity for rapid evolution. Genome Biol. 2015, 16, 71. [CrossRef] [PubMed]

87. McGonigle, S.; Curley, G.P.; Dalton, J.P. Cloning of peroxiredoxin, a novel antioxidant enzyme, from the helminth parasite Fasciola hepatica. Parasitology 1997, 115, 101-104. [CrossRef] [PubMed]

88. Martínez-Sernández, V.; Mezo, M.; González-Warleta, M.; Perteguer, M.J.; Muiño, L.; Guitián, E.; Gárate, T.; Ubeira, F.M. The MF6p/FhHDM-1 major antigen secreted by the trematode parasite Fasciola hepatica is a heme-binding protein. J. Biol. Chem. 2014, 289, 1441-1456. [CrossRef] [PubMed]

89. Donnelly, S.; O’Neill, S.M.; Stack, C.M.; Robinson, M.W.; Turnbull, L.; Whitchurch, C.; Dalton, J.P. Helminth cysteine proteases inhibit TRIF-dependent activation of macrophages via degradation of TLR3. J. Biol. Chem. 2010, 285, 3383-3392. [CrossRef]

90. Donnelly, S.; O’Neill, S.M.; Sekiya, M.; Mulcahy, G.; Dalton, J.P. Thioredoxin peroxidase secreted by Fasciola hepatica induces the alternative activation of macrophages. Infect. Immun. 2005, 73, 166-173. [CrossRef] [PubMed] 
91. Donnelly, S.; Stack, C.M.; O’Neill, S.M.; Sayed, A.A.; Williams, D.L.; Dalton, J.P. Helminth 2-Cys peroxiredoxin drives Th2 responses through a mechanism involving alternatively activated macrophages. FASEB J. 2008, 22, 4022-4032. [CrossRef]

92. Robinson, M.W.; Donnelly, S.; Hutchinson, A.T.; To, J.; Taylor, N.L.; Norton, R.S.; Perugini, M.A.; Dalton, J.P. A family of helminth molecules that modulate innate cell responses via molecular mimicry of host antimicrobial peptides. PLoS Pathog. 2011, 7, e1002042. [CrossRef] [PubMed]

93. Robinson, M.W.; Alvarado, R.; To, J.; Hutchinson, A.T.; Dowdell, S.N.; Lund, M.; Turnbull, L.; Whitchurch, C.B.; O'Brien, B.A.; Dalton, J.P.; et al. A helminth cathelicidin-like protein suppresses antigen processing and presentation in macrophages via inhibition of lysosomal vATPase. FASEB J. 2012, 26, 4614-4627. [CrossRef] [PubMed]

94. Lund, M.E.; Greer, J.; Dixit, A.; Alvarado, R.; McCauley-Winter, P.; To, J.; Tanaka, A.; Hutchinson, A.T.; Robinson, M.W.; Simpson, A.M.; et al. A parasite-derived 68-mer peptide ameliorates autoimmune disease in murine models of Type 1 diabetes and multiple sclerosis. Sci. Rep. 2016, 6, 37789. [CrossRef] [PubMed]

2017 by the authors. Licensee MDPI, Basel, Switzerland. This article is an open access article distributed under the terms and conditions of the Creative Commons Attribution (CC BY) license (http:// creativecommons.org/licenses/by/4.0/). 